\title{
Exercise-induced urticaria and angio-oedema with relief from cromoglycate
} insufflation

\author{
S. HATTY \\ M.B., B.S. \\ G. J. MUFTI \\ M.B., Ch.B., M.R.C.P., M.R.C.Path. \\ Department of Haematology, Royal Victoria Hospital, Boscombe, Dorset
}

M.B., B.S., M.R.C.Path., D.T.M.\&H.

\begin{abstract}
Summary
The pathogenesis of physical urticarias is unknown and the treatment is often difficult and unsatisfactory. A patient with severe exercise-induced angio-oedema and urticaria is reported who responded dramatically to cromoglycate by insufflation and not when treated with orally active cromoglycate.
\end{abstract}

KEY WORDS: angio-oedema, urticaria, cromoglycate.

\section{Introduction}

A variety of physical stimuli including trauma, vibration, light, cold and heat may induce urticaria or angio-oedema in susceptible individuals.

Treatment of the physical urticarias is unsatisfactory since the removal of the cause may be difficult or unwelcome and the use of antihistamines may lead to unacceptable side effects.

We report a patient with severe exercise-induced angio-oedema which responded to cromoglycate by insufflation but not by mouth.

\section{Case report}

A 21-year-old salesman presented with an 18month history of swelling of eyelids, lips and foreskin following exercise. He engaged in a number of sporting pursuits and was extremely fit. The attacks generally came on following indoor exercise, particularly squash or badminton, but on one occasion had developed on the football field. The swelling, which was of sudden onset and accompanied by urticaria of the limbs, had the characteristics of angio-oedema and usually lasted for less than an hour. During the worst attacks, he also complained of itchy ears, abdominal pain and swelling in the throat.

Since childhood he had suffered from ichthyosis, a condition also present in a maternal uncle and wellcontrolled by $10 \%$ urea cream. There was no family history of urticaria or angio-oedema but his father suffered from severe asthma which was sometimfs exercise-induced.

On examination, he was slim and athletic wion well-controlled ichthyosis and no other abnormal physical signs but dermatographia could be demostrated on his back. Investigations showed normal full blood count, urea and electrolytes, liver functiôn tests, lung function tests and chest X-ray. Comp $\bar{E}$ ment studies showed $\mathrm{C}_{3} \quad 0.75 \mathrm{~g} /$ litre (normal rônge $0.55-1.2$ ),$C_{4} 0.3 \mathrm{~g} /$ litre (normal range $0.2-0.5 \frac{8}{2}$ esterase inhibitor $0.35 \mathrm{~g} /$ litre by immunoche assay (normal range 0.15-0.35) and $593 \mathrm{iu} /$ litre $5 y$ functional assay (normal range 336-618). Serum I measured by radioimmunoassay was $220 \mu / \mathrm{ml}$ (noㄱ$\mathrm{mal}<140 \mu / \mathrm{ml}$ ) before exercise and $275 \mu / \mathrm{ml}$ afte wards.

He was treated with orally active cromoglycate (Nalcrom), $8100 \mathrm{mg}$-tablets per day for 1 month without benefit and then started on cromoglycate by insufflation, $20 \mathrm{mg}, 3-4$ times daily. Following the treatment no further attacks of angio-oedema oscurred despite violent exercise. After 6 months treatment he discontinued the cromoglycate of his own volition. Within a week, attacks of exercise.induced angio-oedema recurred. Since restartipg cromoglycate insufflations, he has had no further attacks.

\section{Discussion}

Exercise is one factor that can precipitate cholinergic urticaria. The rise in the body core temperatu releases histamine and factors chemotaxic for neutro phils and eosinophils from mast cells (Soter et at, 1980). In about one-third of such patients, the lesions can be reproduced by injection of cholinergic agents (Commens and Greaves, 1978). Although angi\&oedema does not normally occur in such patients, iu 
forms part of a continuum with urticaria and simply implies that mast cells are degranulating at a deeper level within the dermis.

Cromoglycate has an established place in the treatment of asthma. It is not normally used to treat urticaria, although a single report attests to its usefulness as a topical application for facial urticaria (Silverman, 1973). Cromoglycate acts by inhibiting the transport of calcium ions across mast cell membranes, preventing the release of inflammatory mediators. Only $1 \%$ is absorbed when the drug is taken orally (Cox, 1970) which probably accounts for its failure in our patient when taken in this way. When given by insufflation, $9 \%$ is absorbed from the lungs (MacDonald, 1982) and this seems to be sufficient to exert an effect on mast cells throughout the skin and mucous membranes.

The physical urticarias are difficult to treat since removal of the cause is often inappropriate and the large doses of antihistamine or anticholinergics required may produce side effects worse than the disease (MacDonald, 1982). On the basis of this case, cromoglycate deserves a more widespread trial.

\section{References}

Commens, C.A. \& Greaves, M.W. (1978) Tests to establish the diagnosis of cholinergic urticaria. British Journal of Dermatology, 98, 47.

Cox, J.S.G. (1970) Review of chemistry, pharmacology, toxicity, metabolism, specific side-effects anti-allergic properties in vitro and in vivo of disodium cromoglycate. In: Disodium Cromoglycate in Allergic Airways Disaster (Eds. J. Pepys \& A.W. Frankland), p. 13. Butterworth, London.

MacDonald, C.J. (1982) Cholinergic and cold urticaria. Postgraduate Medicine, 71, 216.

SilvermaN, G. (1973) Topical disodium cromoglycate. British Medical Journal, 2, 502.

SOTER N.A., WASSERMAN, S.I., AUSTEN, K.F. \& McFadden, E.R (1980) Release of mast cell mediators and alterations of lung function in patients with cholinergic urticaria. New England Journal of Medicine, 302, 604.

(Accepted 7 December 1982) 